\title{
The Effect of Job Engagement on Job Burnout and Job Performance: The Moderating Effect of Organizational Justice
}

\author{
Nan Yin $^{1}$ \\ ${ }^{1}$ CHINA-ASEAN International College, Dhurakij Pundit University, Thailand \\ Correspondence: Nan Yin, CHINA-ASEAN International College, Dhurakij Pundit University, Thailand. Email: \\ kitupfor@163.com
}

Received: February 23, 2017

Accepted: March 25, 2017 Online Published: April 27, 2017

doi:10.5539/ijbm.v12n5p177

URL: https://doi.org/10.5539/ijbm.v12n5p177

\begin{abstract}
This study took salemen as an example to explore the relationship between job engagement and job burnout, job engagement and job performance. When studying on the impact of job engagement, both of the two results should be taken into consideration, so the study took job burnout and job performance as the outcome variables of job engagement. The study randomly chose 48 companies of them through field visits, and the respondents were the employees who were engaging in the sales in the 48 computers and computer parts sales companies. When compiling the questionnaires, the paired questionnaire was adopted. 633 employee questionnaires were distributed to the employees and 150 supervisor questionnaires to the supervisors. Each sales department supervisor consists of several employees. Effective recovery of the questionnaire was 501 copies. The results show that job engagement positively affects task performance and organizational citizenship behavior in job performance, and negatively affects counterproductive work behavior; Job engagement negatively affects job burnout, and organizational justice has a significant negative moderating effect on job engagement and counterproductive work behavior.
\end{abstract}

Keywords: job engagement, job burnout, job performance, organizational Justice, Salesmen

\section{Research Background and Motivations}

High job performance usually needs high levels of job engagement, which was relatively well studied in the past, but high levels of job engagement also could result in job burnout. When an employee invested too much energy in the job, it might cause the phenomenon of job burnout. The enterprises should pay attention to the phenomenon of job burnout caused by high levels of job engagement of the employees while asking the employees to generate high job performance. If the job burnout of the employees was produced, they would lack the motivation on working affairs. For an enterprise, if the employees had a sense of job burnout because of working exhaustedly and tiredly for a long time, it would had certain impact on the individual job performance of the employees and operating performance of the enterprise. Job burnout would impact individual's body, mind and work, and also the performance of the organization which the individual was in(Wong, 2000). Because of the negative impact of job burnout, the business started to focus on how to solve that problem, the same with the scholars. So it is necessary for the modern enterprise managers to find a balance between the improvement of job performance and the reduction of job burnout of the employees. The study just took the previous research approach as the start point of the study.

Job engagement is to what degree individual's mental acceptance to work; or the importance of work in individual's mind (Sonnentag, 2003). Warr and Inceoglu (2012) assumed that job engagement was that the individuals approved the value of the jobs and they are willing to work, and at the same time they took work as their life orientation and highlighted job evaluation and job performance so as to meet the demand of self-esteem, and then the degree of working hard and focusing on the job was produced. Job engagement is the mental efforts devoted by the employees to work, which has a positive impact on the performance of an organization, because job engagement was the degree of individual's concentration on work (Brooke, Russell, \& Price, 1988). All the more engaged workers will highly approve and concern their jobs, and they think that work is the main source of satisfying important demand and the important part of mental life (Sonnentag, 2003). From the definition of job engagement in the previous literaures, job engagement is the individual's acceptance degree to work and the active working state of the employees. Therefore, the study discusses whether the job engagement of the 
employees in the active state will definitely bring job performance, which is the first motivation of the study.

Job engagement received much attention from the enterprises, because according to the previous correlational research on job engagement, job engagement has a positive impact on organizations and work. In the field of organization, job engagement will reduce absenteeism (Scott \& Mcclellan, 1990), decrease turnover (Xanthopoulou, Bakker, Demerouti, \& Schaufeli, 2009), promote performance (Brown \& Leigh, 1996), enhance in-role performance and strengthen organizational citizenship behaviors (Diefendorff, Brown, Kamin, \& Lord, 2002). In the field of work, job engagement will improve the effort (Brown \& Leigh, 1996), job satisfaction, job accuracy, and completeness of communications (Orpen, 1997). However the previous researches mainly focused on the positive impact of job engagement, there was little researches on the negative impact of job engagement. The study assumed that appropriate job engagement would increase job performance, but excessive job engagement will result in job burnout. But it could not be proved by the previous researches that to what degree job engagement could generate job performance, so the aim of the study is to find the balance between job performance and job burnout with the job engagement as a fulcrum, which is the second motivation of the study.

Organizational justice includes three components, distributive justice, procedural justice and interactional justice, and the basic hypothesis is: individuals internal to an organization are always in a state of social comparison, and they would compare their reward to engagement ratios with the others' and concern that whether the comparative results between themselves and the others is justice. Organizational justice is perceptions of fairness of individuals internal to that organization in treating the organization system, policies and measures related to the self-interests. The higher the degree of fairness of an organization is, the higher the possibility of perceiving being treated fairly for the employees is, and then they will be more engaged and decrease job burnout and improve the job performance, so organizational justice can be taken as a moderator for adjusting the relationship among job engagement, job performance and job burnout, which is the third motivation of the study.

At present, many researchers studied the relationship between job engagement and job burnout, the relationship between job engagement and job performance and so on, but there is no study on the relationship among job engagement, job burnout and job performance from a systematic perspective. Whether job engagement will impact job performance or lead to job burnout is a question worth thinking. Based on that, the study takes job engagement as the fulcrum to study the relationship between job engagement and job burnout, job engagement and job performance.

\section{Literature Reviews and Hypotheses}

\subsection{Outcome Variables of Job Engagement}

As an active and fulfilling working state, the positive impact of job engagement on the job has been widely agreed (Saks, 2006). The outcome variables related to job engagement in the present research mainly include: job satisfaction, job performance, Organizational Citizenship Behavior, sense of happiness (Hallberg \& Schaufeli, 2006), turnover intention (Schaufeli \& Bakker, 2004) and so on. However, the former researches mainly discuss the positive impact of job engagement and rarely the negative impact of job engagement. The study assumes that proper job engagement will increase job performance but excessive job engagement will result in job burnout, so the job engagement of the employees generates high job performance while it generates job burnout. Both of the positive and negative impacts of job engagement are taken into consideration-that is trying to find a balance between job performance and job burnout.

\subsection{The Impact of Job Engagement on Job Performance and Job Burnout}

Job engagement is a kind of positive emotion one can perceive in the work. Positive emotion has been proved that both the initiative positive emotion and the induced positive emotion contribute to solving problems and making decisions effectively (Baumann \& Kuhl, 2005). The positive emotional state is conducive to the cognitive processing of information, so it can directly affect job performance (Wong, 2000). When the mental representation of a behavior objective is connected with positive emotion, the mental representation will automatically send information to the individual, and this objective is a locomotor activity which is worth doing and promote the individual to accomplish the objective (Custers \& Aarts, 2005). The same with other positive emotion, job engagement is also conducive to produce objective behavior and approach behavior(Ng \& Feldman, 2008), so as to stimulate the individual to engage into the work or work environment, so the positive emotion contributes to increasing performance (Adler, Mclaughlin, \& Rogers, 2006). Christen, Iyer, and Soberman (2013) think that the enthusiasm for the job and the level of involvement is job engagement, and the higher the level of job engagement of the employees, the higher the intention to work hard. And they can generate more productive forces than others and satisfy the demand of the customers, and illustrate the performance for the organization to reach the ultimate expectation. 
The employees often can obtain the sense of significance and satisfaction at work, and they are full of hope for the future development and improvement and take job performance as the proof of their ability (Avey, Luthans, \& Youssef, 2010). Job engagement emphasizes the emotional relevance with the job and reflects their affection and proficiency of the job, and the employees regard producing high-quality work as their own responsibility, so it can change the job performance of the employees (Wong, 2000).

Sonnentag (2003) defines job engagement as "the members of the organization control themselves in order to make themselves combine with the job role". Self and job role actually in the dynamic and reciprocal transformation process: when the individual is more engaged, he/she will devote his/her energy into self-employment and self-expression in the role and then generate job performance; on the contrary, when the individual is less engaged, he/she will extract himself/herself from the job role so as to avoid to generate job performance needed by the job role and might generate turnover intention.

According to the above literature reviews, the study assumes that job engagement is a kind of value recognition held by the individual toward the job- that is the degree of the importance of the job the individual recognizes. When the individual perceives that one can generate job performance through one's endeavor, one will be engaged into the work (Hackman \& Lawler, 1971). The job engagement of the employees shows the recognition of job in the employees' mind. They will devote individual's energy into the job role and regard job performance as the reflection of personal value and show self-expression in the role, so it might increase the job performance of individual. The study puts forward the following hypothesis:

Hypothesis 1: The job engagement of the employees will increase job performance-that is job engagement is positively related to job performance.

In recent year, the definition of job performance has been expanded into three performance behaviors, namely core task behavior, organizational citizenship behavior and counterproductive behavior. Rotundo and Sackett (2002) assumed that core task behavior, organizational citizenship behavior and counterproductive behavior all have an impact on the overall performance, and the core task performance has the highest weight, and then is counterproductive performance and organizational citizenship behavior performance.

The definition of job performance in this study is the combination of three performance behaviors, namely core task behavior, organizational citizenship behavior and counterproductive behavior. Task performance describes behaviors contributed to the core technology of the organization, the same with Borman, Penner, Allen and Motowidlo's definition of task performance (Schaufeli, Bakker, \& Rhenen, 2009a); organizational citizenship behavior is defined as voluntary personal behavior of the employee and has no direct and obvious connection with formal incentive system, but it can promote the organizational function as a whole(Smith, Organ, \& Near, 1983); counterproductive performance is that employees violate the formal regulations of the organization and the intentional actions by employees which circumvent the interest of the organization or the members of the organization.

The study assumes that core task performance has the closest relationship with job performance, so according to the analyzing result of Hypothesis 1, the following hypothesis is put forward:

Hypothesis 1a: The job engagement of the employees will increase core task performance-that is job engagement is positively related to core task performance.

Organizational citizenship behavior is defined as individual behavior that is beneficial to the organization, but that is not explicitly or directly recognized by the formal reward system. There are at least 7 dimensions of OCB: helping behavior, sportsmanship, organizational loyalty, organizational compliance, individual initiative, civic virtue, and self-development. OCB is an employee's voluntary commitment within an organization or company that is not part of his or her formal work requirement, but it definitely will promote the effective functioning of the organization.

OCB is defined as individual behavior that is discretionary, not directly or explicitly recognized by the formal reward system, and that is conducive to promote the effective functioning of the organization. These behaviors usually go above and beyond the employees' job description, and are performed by the employee as a result of personal choice. They are not related to any formal reward system and also not the in-role behavior (Hoffman, Blair, Meriac, \& Woehr, 2007).

As time goes by, OCB in the aggregate promotes the performance of the organization. The specific performance is: citizenship behavior is conducive to form the positive team atmosphere and create the job circumstances which make people feel happier, and which can enhance the environmental adaptive capacity of the organization, and which can create the social capital of the organization and then promote the work efficiency of the 
employees and the performance of the organization (Blickle, Wendel, \& Ferris, 2010).

According to the above literature reviews, the study assume that although OCB is not the requirement of the formal job of the employees, it does not conflict with the organizational work but it is the behavior that is performed by the employee as a result of personal choice and that promotes the effective functioning of the organization. The three components (energy, contribution and focus) of job engagement are the direct successors of the factors of OCB, organizational loyalty, organizational compliance and self-development (Hakanen, Perhoniemi, \& Toppinen-Tanner, 2008). Job engagement shows that the employees recognize this job from the heart and wish to show the self- expression in the job, and that is also a kind of self-sacrifice behavior, so it can promote the performance of OCB. In accordance with the reasoning process, the study puts forward the following hypothesis:

Hypothesis 1b: The job engagement of the employees will increase the performance of Organizational Citizenship Behavior -that is job engagement is positively related to the performance of Organizational Citizenship Behavior.

Counterproductive work behavior (CWB) is defined as any intentional personal behavior that is harmful to the legitimate interests of an organization or the stakeholders of the organization. Although people recognized the multi-dimensional nature of job performance long time age (Schaufeli et al., 2009), until the recent decade, the researchers just began to seek the Contextual Performance besides task performance, and the employees' performance behaviors were divided into in-role behavior and extra-role behavior. The former is the job behavior that the employees accomplish the tasks required by the organization, and the latter is the voluntary behavior that goes above and beyond that which is required by the organization. After the 1980s, with the rise of the definition and study on Organizational Citizenship Behavior, it indirectly provides theoretical foundation for counterproductive behavior.

Among the studies on job performance structure, some negative behaviors are harmful for the interest of the organization or of the employees, for example: theft, fighting, forming a personal-interest clique, and which are defined as the counterproductive behaviors (Penney \& Spector,2005). So counterproductive behaviors are the intentioanl employee behaviors that go against the legitimate interests of an organization or the menbers of the organization and against the legimate regulations of the organization.

The studies on the outcome variables of counterproductive work behavior are mainly related to job performance. Rotundo and Sackett (2002) proposed three performance fields: job performance, organizational citizenship behavior, counterproductive work behavior. From the angle of job behavior, job performance can be divided into task performance and non-task performance. Non-task performance is divided into two performance behaviors with different effect: when focusing on positive non-task performance, it is defined as organizational citizenship behavior or contextual performance; when focusing on negative non-task performance, it is defined as counterproductive work behavior.

According to the definition of counterproductive work behavior in the previous literautre reviews, the study assumes that when the employees are engeged, it shows that employees recognize this job from the heart and will devote individual's energy into job role and regard job performance as the reflection of person value. Counterproductive work behavior is the negative behavior that goes against the interest of the organizaiton or of the members, so it conflicts with positive job engagement. According to this reasoning process, the study puts forward the following hypothesis:

Hypothesis 1c: The job engagement of the employees will decrease counterproductive behavior-that is job engagement is negatively related to counterproductive work behavior.

Job engagement will impact the job performance and turnover intention of employees, and that is an important employee job attitude. When the individual thinks highly on his job, he will be more engaged. When facing too much job stress, the individual will perceive emotional exhaustion and lose the original intention, commitment and achievability toward the job, and this kind of phenomenon is defined as job burnout. When the individual invest too much energy into the job, he will feel sick of job, and which might result in job burnout. Those who are engaged too much and take the job as the main part of their life are easier to perceive emotional exhaustion. Because if attaching too much importance to the job and the outcome of the job, a high level of stress will be caused, so it is easy to generate job burnout (Schaufeli, Bakker, \& Rhenen, 2009).

According to the above literature reviews, the study assumes that high levels of job engagement will make the employees generate negative feelings and emotion, and they will feel sick of the job and which might result in job burnout, so the following hypothesis is put forward: 
Hypothesis 2: The job engagement of the employees will increase job burnout-that is job engagement is positively related to job burnout.

\subsection{The Moderate Effect of Organizational Justice on the Relationship between Job Engagement and Job Burnout}

Organizational justice is defined as "people in an organization or a company feel a sense of justice about the organizational system, policy and measures related to individual's interest; social justice is classified into different groups according to these characteristics, such as different classes, industries and occupations and so on Justice in an organization can also be divided into two levels: the first one is the objective state of organizational justice. On this level, people can continuously perfect and develop all kinds of organizational systems and establish appropriate procedures and measures to achieve organizational justice, but absolute and ultimate organizational justice is hard to be realized. The second level is organizational justice-that is the organizational members' objective perceptions about organizational justice. They have connections and also differences. If a "justice system" cannot be recognized and accepted by the employees, it cannot achieve its full play to impact the employees' behaviors (Greenberg, 2010). So from the angle of Organizational Behavior, organizational justice is more important, and the discussion about the problem of justice is mainly about organizational justice.

Organizational justice is related to many employee behaviors which are positive and conducive to the realization of the organization target (Rupp, Ganapathi, Aguilera, \& Williams, 2006). The relationship between organizational justice and personal performance is mainly represented by the impact of distributive justice and procedural justice on performance. According to the theory of Adams, if the individual perceives a sense of justice with a resulting reward of his engagement, he will be dedicated to his jobs and work hard; if not, he will reduce the degree of hard working and go slow, at most accomplish the work requirement (Heponiemi, Manderbacka, Vänskä, \& Elovainio, 2013). The realization of procedural justice could ensure the long time interest of employees and has positive impact on performance. Research findings suggest that organizational justice will decrease job burnout of employees (Bell, Wiechmann, \& Ryan, 2006).

Based on the above literature reviews, the study suggest that in accordance with the justice theory of Adams, employees' sense of justice mainly comes from the perceptions of justice with the quantity of reward. They always compare the ratio of their own outcome (i.e. the reward obtained from the organization) to their investment (including the following factors one possesses, namely: skills, endeavor, education, training, experience) with the ratio of other's outcome to investment. When the ratios are not equal, the sense of injustice will be produced. This sense of injustice will make the individual experience nervous or anxiety and they will seek ways to rebuild justice. Employees may compare the ratio of their own investment to their outcome (i.e. the reward) with the ratio of other's investment to outcome. If the ratios are not equal, the sense of injustice will be produced, which will result in nervous or anxiety and then arouse job burnout. The degree of sense of justice might impact the relationship between job engagement and job burnout-that is the lower the sense of justice (the higher the sense of injustice), the higher the impact of job engagement on job burnout. So according to the above analysis, the following hypothesis is put forward:

Hypothesis 3: Organizational Justice plays a negatively moderate role in the relationship between job engagement and job burnout; that is the lower the degree of organizational justice, the higher the influential degree of job engagement on job burnout.

\subsection{The Moderate Effect of Organizational Justice on the Relationship between Job Engagement and Job Performance}

The justice theory of Adams suggests that the motivations of human beings are impacted by the comparison between their own investment and outcome and other's investment and outcome. When employees perceive injustice, they will change in behavior or attitude or change the both, for example: a drop in productivity and vice versa. In other words, if the individual does not obtain the deserved reward according to one's investment, one will perceive the sense of injustice which could arouse nerve and result in a drop of job engagement. Greenberg (2004) argues that procedural justice changes the relationship between employees and the organization from a kind of economic exchange into a kind of social exchange. In the social exchange relationship, when employees perceive satisfied with procedural justice, they might generate voluntary commitment as a return which is out of formal role requirements. These extra-role behaviors involve contextual performance. In addition, procedural justice includes fair procedure, for example: employees are permitted to participate in the process of decision making and treated fairly, including providing information to employees to explain their outcome which might increase the possibility of justice (Ambrose \& Schminke, 2009). Thus employees are more probably to perceive satisfaction and then carry out his contractual duties. Rupp, Ganapathi, 
Aguilera, and Williams (2006) support the positive relationship between procedural justice judgment and task performance, and others also provide evidences for the positive impact of procedural justice on contextual performance (Colquitt \& Shaw, 2005).

According to the definition of organizational justice and references, the study suggests that employees may compare the ratio of their own investment to their outcome (i.e. the reward) with the ratio of other's investment to outcome. If the ratios are not equal, the sense of injustice will be produced, which will result in nervous or anxiety and then impact their job engagement. The job engagement of the employees shows the recognition of job in the employees' mind. They wish to show self-expression at work and regard job performance as the reflection of personal value, so the degree of the sense of justice might impact the relationship between job engagement and job performance-that is the higher the organizational justice (the lower the sense of injustice), the larger the impact of job engagement on job performance. The following hypothesis is proposed:

Because job performance include three performance behaviors, namely core task behavior, organizational citizenship behavior and counterproductive work behavior (Rotundo \& Sackett, 2002). From the angle of job behavior, job performance can be broken into task performance and non-task performance. Non-task performance is also divided into two performance behaviors with different effect: when focusing on positive non-task performance, it is defined as organizational citizenship behavior or contextual performance; when focusing on negative non-task performance, it is defined as counterproductive work behavior. As is known from the above literature, core task performance belongs to task perfromance, and it has the closest realtionship with job performance. Although OCB is not the requirement of the formal job of the employees, it does not conflict with the organizational work but it is the behavior (positive non-task performance) that is performed by the employee as a result of personal choice and that promotes the effective functioning of the organization. Counterproductive work behavior is the negative behavior that goes against the interest of the organizaiton or of the members, and it also can affect organizational performance, so it might conflict with positive job engagement (Rotundo \& Sackett, 2002). The following hypothesis is proposed:

Hypothesis 4a: Organizational justice has a positive moderating effect on the relationship between job engagement and core task performance.

Hypothesis 4b: Organizational justice has a positive moderating effect on the relationship between job engagement and organizational citizenship behavior.

Hypothesis 4c: Organizational justice has a negative moderating effect on the relationship between job engagement and counterproductive work behaviors.

\section{Research Framework}

Based on the above literature reviews, the study builds the research framework as follows, shown in Figure 1.The research framework shows that the job engagement of the employees could bring two kinds of results, that is job burnout and job performance, and then how to balance job burnout and job performance is the fundamental aim of building theoretical framework in this study. At the same time, in order to make the research framework be more typical, organizational justice is the moderator adjusting job engagement and job performance, job engagement and job burnout. Job performance can be also classified into three dimensions, namely task performance, organizational citizenship behavior and counterproductive work behavior.



Figure 1. Research Framework

Notes. OCB: Organizational Citizenship Behavior, CWB: Counterproductive Work Behavior 


\section{Sample and Methodology}

Under the background of knowledge economy, informatization and globalization, many enterprises are confronted with significant market risk and increasing pressure. Under this circumstance, salesmen's work stress is rising with the higher and higher requirement of quality and ability of salesmen. That the salesmen have too much pressure is a universal phenomenon now. The professional nature of salesmen decides that the practitioners endure more mental stress and work challenge than ordinary people, so the study takes salesman as the research object.

With real professional environment as research target and actual working personnel as sampling object, the study adopted the parent who was the small and medium-sized computers and computer parts sales company in Nanjing. In view of Statistical Yearbook of Nanjing in 2015, there are 276 computers and computer parts sales companies in Nanjing area. The study randomly chose 48 companies of them, and the respondents were the employees who were engaging in the sales in the 48 computers and computer parts sales companies. 633 employee questionnaires were distributed to the employees and 150 supervisor questionnaires to the supervisors. Each sales department supervisor consists of several employees. Effective recovery of the questionnaire was 501 copies.

Because all the employees working as salesmen bear great work pressure and have certain business performance indicators, if they cannot reach the requirement, their salary or bonus will be deducted by the enterprise, so the salesmen need to be engaged. In addition, the study mainly focuses on the job performance of the employees, but employees are hard to evaluate their own job performance, so objective results might be obtained through the evaluations of supervisors on employees' performance. Because in an organization, supervisors have the power to evaluate employees' performance, it is practical to use the supervisors' evaluation when measuring job performance (task performance, organizational citizenship behavior and counter-productive behavior) of employees. When compiling the questionnaires, the paired questionnaire was adopted, that is to say, questionnaire survey was carried out in the way of combining the employees and the supervisors. In this way, we could receive the typical research findings which can test the hypotheses in the study.

The number of the research samples decides that the referenced analysis method is structural equation modeling (SEM). Schumacker and Lomax (1996) argue that according to the literature review, if the sample number is less than $100-150$, it is an instability model, and most of the literatures adopted 250-500 samples, so a total of 783 questionnaires were distributed (including the employee questionnaire and the supervisor questionnaire). Before distributing questionnaires, the researcher firstly got in touch with the contact of the enterprise, and then personally distributed the questionnaires in the enterprise and explicated to the participants the content of the questionnaire, answering method and relevant notes; for enhancing answering willingness, a small gift was given to the participants before answering.

\section{Survey Instrument}

The scales in the questionnaire are widely used in foreign counties, and all the items adopted the five-level Likert scale, falling into Strongly disagree $(=1)$, Disagree $(=2)$, Neither agree nor disagree $(=3)$, Agree $(=4)$, and Strongly agree $(=5)$. Participants were asked to evaluate by giving it a quantitative value from 1 to 5 with level of agreement/disagreement being the dimension. In the light of literature reviews, the operating and measuring method of the variables in the research framework was proposed, and those are stated in the following:

(1) Job engagement is the degree of importance of the job individual recognized. The scale was based on the job engagement scale proposed by Schaufeli et al. (Schaufeli, Salanova, González-Romá, \& Bakker, 2002), including three dimensions-Vigor, Dedication and Absorption, which are used to measure the recognition perceptions of employees on job engagement. The participants chose the appropriate degree according to their own feelings. The higher the participant's score was, the higher the recognition degree was. The reliability and validity of the scale is good and the Cronbach's $\alpha$ value of the scale is 0.73 (Biggs, Brough, \& Barbour, 2014).

(2) Organizational justice in the study is based on the view point of Niehoff and Moorman (Niehoff \& Moorman, 1993). Distributive justice is defined as employees' perception degree of the organization using fair ways to distribute reward; Procedural justice is conceptualized as employees' perception degree of organization making decisions with fair way and rules; Interactive justice refers to whether the employees are treated fairly and whether the organization has explained the decision-making process before the organization completes the decision. The scale measuring organizational justice is developed from the scale of Niehoff and Moorman(Niehoff \& Moorman, 1993), which divides organizational justice into three dimensions, distributive justice, formal procedures and interactional justice. There are 20 items in all and three sections: distributive justice has 5 items, procedural justice has 6 items and interactional justice has 9 items. The participants choose 
the appropriate degree according to their own feelings. The higher the participant's score was, the higher the organization justice perception degree was. The reliability and validity of the scale is good and the Cronbach's $\alpha$ value of the scale is 0.75 (Colquitt \& Shaw, 2005).

(3) The aim of the scale is to understand the degree of job burnout. The scale takes Maslach and Jackson's Maslach Burnout Inventory (MBI) (Maslach \& Jackson, 1981) as the compiling framework. All the dimensions of job burnout are illustrated as follows: 1.Emotional exhaustion: It refers to the phenomenon that employee perceive that emotional resource exhausts day by day and feel tired in physiology and psychology, and that they cannot contribute their mental and physical efforts any more. Question no. 1-9, 9 items in all. 2. Personal accomplishment: it refers that employees generate positive evaluation of themselves, have the sense of achievement and perceive contented with their performance in the work. Question no.10-17, 8 items in all. 3 . Depersonalization: It is defined as the passive, indifferent and negative attitude that employees use to treat the service objects. This kind of employees becomes bad tempered and is easy to feel anger, and even feel indifference to the things around them. Question no.18-22, 5 items in all. Participants filled in the scale according to their feelings. The higher the participant's score was, the higher the job burnout degree was. The reliability and validity of the scale is good and the Cronbach's $\alpha$ value of the scale is 0.73 (Schaufeli \& Van Dierendonck, 1993).

(4) The definition of job performance in the study is the combination of three performance behaviors: core task behavior, organizational citizenship behavior and counterproductive work behavior. Task performance describes behaviors contributed to the core technology of the organization; organizational citizenship behavior is defined as voluntary personal behavior of the employee and has no direct and obvious connection with formal incentive system, but it can promote the organizational function as a whole; counterproductive work behavior is that employees violate the formal regulations of the organization and the intentional actions by employees which circumvent the interest of the organization or the members of the organization.

The measurement of core task performance adopted the scale developed by Tsui et al. (Tsui, Pearce, Porter, \& Tripoli, 1997), and there are 11 items, for example: "Employee's quantity of work is higher than average" and "Employee's standards of work quality are higher than the formal standards for this job. The scale of organizational citizenship behavior adopted the scale compiled by Lee and Allen (Lee \& Allen, 2002) who proposed the two dimensions: OCB-Interpersonal and OCB-Organizational, with 16 items in all. The reliability and validity of the scale is good and the Cronbach's $\alpha$ value of the original questionnaire is 0.7 . The scale of counterproductive work behavior adopted the scale with 19 items including interpersonal deviance and organizational deviance developed by Bennett and Robinson (Bennett \& Robinson, 2000). The reliability and validity of the scale is good and the Cronbach's $\alpha$ value of the original questionnaire is 0.77 .

\section{Results}

\subsection{Correlation Analysis}

This study makes the relevant analysis towards the variables in scales in order to discuss the possible correlations among variables and factor sub dimensions in scales including job engagement, job burnout, task performance, organizational citizenship behavior (OCB), etc.

According to Table 1, the value of AVE in every dimension is higher than .5 and AVE is higher than the square of correlation coefficient, which indicates that the scale has a good convergent validity and discriminant validity.

Correlation coefficients of job burnout, task performance, OCB, CWB and job engagement are respectively $-.31, .2, .24$ and -.17 , and significance is .00 , which indicates that there is a significant negative relationship between job burnout, CWB and job engagement, and a significant positive relationship between task performance, $\mathrm{OCB}$ and job engagement. Correlation coefficients of organizational justice and job burnout have a significance higher than .05 , indicating that there is no significant relationship between organizational justice and job burnout. Correlation coefficients of organizational justice and task performance have a significance higher than .05 , indicating that there is no significant relationship between organizational justice and task performance. Correlation coefficients of organizational justice and OCB have a significance higher than .05 , indicating that there is no significant relationship between organizational justice and OCB. Correlation coefficients of organizational justice and CWB have a significant higher than .05 , indicating that there is no significant relationship between organizational justice and CWB. 
Table 1. Correlation analysis

\begin{tabular}{|c|c|c|c|c|c|c|c|c|c|c|c|c|c|c|c|}
\hline & $\begin{array}{l}\text { Mean } \\
\text { Value }\end{array}$ & $\begin{array}{l}\text { Standard } \\
\text { Deviation }\end{array}$ & 1 & 2 & 3 & 4 & 5 & 6 & 7 & 8 & 9 & 10 & 11 & 12 & 13 \\
\hline 1. Gender & & & & & & & & & & & & & & & \\
\hline 2. Birth Year & & & $.12^{* *}$ & - & & & & & & & & & & & \\
\hline 3.Degree & & & .05 & $.15^{* *}$ & - & & & & & & & & & & \\
\hline 4. Position & & & $-.09^{*}$ & $-.64^{* *}$ & .06 & - & & & & & & & & & \\
\hline 5.Working Years & & & $-.11^{*}$ & $-.92^{* *}$ & $-.24^{* *}$ & $.63^{* *}$ & - & & & & & & & & \\
\hline 6. Enterprise Scale & & & .02 & $-.18^{* *}$ & .07 & $.10^{*}$ & $.19^{* *}$ & - & & & & & & & \\
\hline 7. Team Size & & & .03 & $.14^{* *}$ & -.01 & $-.18^{* *}$ & $-.12^{* *}$ & $.10^{*}$ & & & & & & & \\
\hline 8.Job Engagement & 3.43 & .67 & .03 & .01 & -.01 & -.07 & .01 & .03 & .06 & .74 & & & & & \\
\hline 9.Job Burnout & 3.01 & .71 & -.00 & -.06 & -.07 & .04 & .05 & .08 & .01 & $-.31^{* *}$ & .65 & & & & \\
\hline 10.Task Performance & 3.24 & .78 & -.03 & .09 & .01 & -.05 & -.08 & -.06 & -.01 & $.20^{* *}$ & $-.11^{*}$ & .81 & & & \\
\hline 11.OCB & 3.18 & .70 & .02 & .00 & -.02 & -.01 & -.00 & -.01 & .01 & $.24^{* *}$ & -.02 & $.25^{* *}$ & .70 & & \\
\hline 12.CWB & 2.24 & .72 & .04 & .06 & .04 & 0 & -.06 & .08 & -.07 & $-.17^{* *}$ & .08 & $-.19^{* *}$ & $-.22^{* *}$ & .76 & \\
\hline $\begin{array}{l}\text { 13. Organizationa } \\
\text { Justice }\end{array}$ & 13.44 & .63 & -.03 & -.00 & .01 & .05 & .00 & .03 & -.05 & $-.49^{* *}$ & $.21^{* *}$ & -.02 & -.02 & -.05 & .68 \\
\hline
\end{tabular}

Note. ** was significantly correlated with.01 level (bilateral); * significantly correlated with the .05 level (bilateral); the diagonal value was the square root of AVE.

\subsection{Verification of Convergent Validity}

Composite reliability (CR) is one of the criteria to judge the intrinsic quality of the model, which reflects the consistency of all items in each latent variable. According to Table 2, CR is higher than .7, which is higher than the standard of .6 suggested by Fornell and Larcker (1981), indicating to a good internal consistency.

Convergent validity in different dimensions is usually reflected by mean variance extraction (AVE). The value of AVE is usually used to show convergent validity of the scale. And can show directly how much of the variance is explained by the potential variables. The higher the AVE is, the higher the percentage of the variance is explained by the potential variables, and the lower the relative measurement error is. Table 2 shows that most of AVE values are higher than .5 which is the standard suggested by Fornell and Larcker (1981). In conclusion, according to the data above, this model is acceptable.

Table 2. Standardized Factor Loading

\begin{tabular}{|c|c|c|c|c|}
\hline Variable & Dimension (Items) & Standardized Factor Loading & $\mathrm{CR}$ & AVE \\
\hline \multirow[t]{11}{*}{ Task Performance } & tp1 & .86 & \multirow{11}{*}{.96} & \multirow{11}{*}{.66} \\
\hline & tp2 & .87 & & \\
\hline & tp3 & .87 & & \\
\hline & tp4 & .88 & & \\
\hline & $\operatorname{tp} 5$ & .90 & & \\
\hline & tp6 & .85 & & \\
\hline & tp7 & .81 & & \\
\hline & $\operatorname{tp} 8$ & .73 & & \\
\hline & tp9 & .77 & & \\
\hline & $\operatorname{tp} 10$ & .79 & & \\
\hline & tp11 & .58 & & \\
\hline \multirow[t]{3}{*}{ Job Engagement } & Absorption & .79 & \multirow{3}{*}{.78} & \multirow{3}{*}{.54} \\
\hline & Dedication & .72 & & \\
\hline & Vigor & .69 & & \\
\hline \multirow[t]{2}{*}{ Job Burnout } & Depersonalization & .73 & \multirow{2}{*}{.69} & \multirow{2}{*}{.42} \\
\hline & Personal Accomplishment & .59 & & \\
\hline
\end{tabular}




\begin{tabular}{|c|c|c|c|c|}
\hline Variable & Dimension (Items) & Standardized Factor Loading & $\mathrm{CR}$ & AVE \\
\hline & Emotional Exhaustion & .63 & & \\
\hline \multirow[t]{2}{*}{$\begin{array}{l}\text { Organizational Citizenship } \\
\text { Behavior }\end{array}$} & OCB-Interpersonal & .80 & .64 & .48 \\
\hline & OCB-Organizational & .57 & & \\
\hline \multirow[t]{2}{*}{$\begin{array}{l}\text { Counterproductive Work } \\
\text { Behavior }\end{array}$} & Interpersonal Deviance & .74 & .73 & .58 \\
\hline & Organizational Deviance & .79 & & \\
\hline \multirow[t]{3}{*}{ Organizational Justice } & Distributive Justice & .66 & & \\
\hline & Procedural Justice & .72 & .72 & .46 \\
\hline & Interactional Justice & .66 & & \\
\hline
\end{tabular}

According to Table 2, the normalized factor load in every dimension is higher than .5 , indicating that every item can well explain the dimension it is in. CR is higher than .7, which shows that all the items in each latent variable can be used to explain the latent variable.

\subsection{Structural Equation Model}

Structural Equation Modeling (SEM), also known as Structural Equation Analysis, is a statistical method based on the covariance matrix of variables to analyze the relationship between variables so it can be also called covariance structure analysis. SEM is a multivariate statistical analysis technique that combines multiple regression and factor analysis to evaluate a series of causal relationships automatically.

Table 3. Confirmatory factor fit index

\begin{tabular}{llllllllll}
\hline Index & CMIN & DF & CMIN/DF & GFI & AGFI & NFI & CFI & RMSEA & SRMR \\
\hline $\begin{array}{l}\text { Fit } \\
\text { Index }\end{array}$ & 1577.04 & 553 & 2.85 & .84 & .82 & .86 & .91 & .06 & .05 \\
\hline
\end{tabular}

Generally, a chi square degree of freedom lower than 3.0 indicates a good fitness of model; when the sample size is large, the chi square value is higher, it is also acceptable if it is lower than 5. GFI refers to general fitness index while AGFI refers to adjusted general fitness index. The value of AGFI is between 0 and 1 , and the closer the value is to 1 , the better the fitness of the model is. Generally GFI and AGFI shall be $>.8$. NFI refers to the normalized fitness index while CFI refers to comparative fitness index; the closer the value is to 1, the better the fitness of the model is. Generally NFI and CFI shall be $>.9$. When RMSEA, which indicates asymptotic residual mean square and square root, is lower, the better the fitness of the model is, while generally it is acceptable when it is lower than .8; when it is higher than .1, it is unacceptable. SRMR refers to the sum of the average residual covariance, and it shall be lower than .05 .

According to the table 3, the fitting basically meet the requirements, indicating that the model is acceptable with a SRMR value of .05. Figure 2 represented a SEM model in AMOS, path coefficients in different dimensions and the test results of this questionnaire are concluded as shown in the following table 4 .

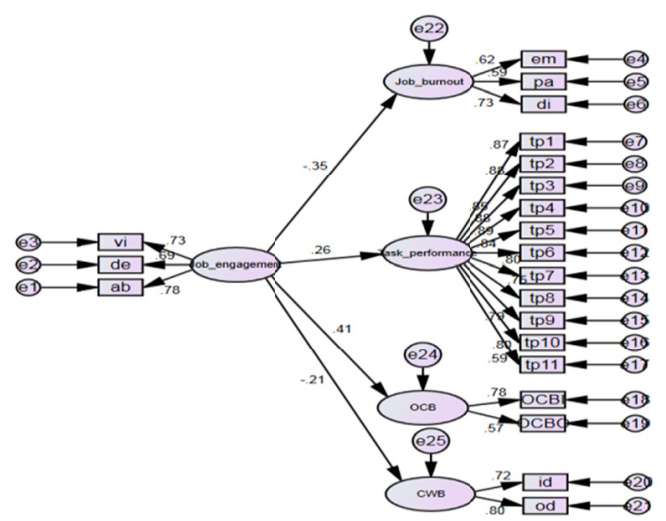

Figure 2. SEM Model with AMOS 
Table 4. Standardized path coefficient

\begin{tabular}{|c|c|c|c|c|c|}
\hline Variables & Path & Variables & $\begin{array}{l}\text { Standardized path } \\
\text { coefficient }\end{array}$ & $\mathrm{T}$ Value & P Value \\
\hline Job Engagement & $\rightarrow$ & Job Burnout & -.35 & -5.51 & $* * *$ \\
\hline Job Engagement & $\rightarrow$ & Task Performance & .26 & 5.22 & $* * *$ \\
\hline Job Engagement & $\rightarrow$ & OCB & .41 & 6.40 & $* * *$ \\
\hline Job Engagement & $\rightarrow$ & CWB & -.21 & -3.09 & .00 \\
\hline
\end{tabular}

Note. $p<.05^{*} ; \quad p<.01^{* *} ; \quad p<.001^{* * *}$.

According to Table 4, the standardized path coefficient of job engagement to OCB is $.41(t=6.40, p=.00<.05)$, which indicates that job engagement has a significant positive impact on OCB, namely a higher job engagement leads to a higher OCB; The standardized path coefficient of job engagement to CWB is $-.21 \quad(t=-3.09$, $p=.00<.05$ ), which indicates that job engagement has a significant negative impact on CWB, namely a higher job engagement leads to a lower CWB; The standardized path coefficient of job engagement to job burnout is $-.35(t=-5.51, p=.00<.05)$, which indicates that job engagement has a significant negative impact on job burnout, namely a higher job engagement leads to a lower job burnout; The standardized path coefficient of job engagement to task performance is $.26(t=5.22, p=.00<.05)$, which indicates that job engagement has a significant positive impact on task performance, namely a higher job engagement leads to a higher task performance.

\subsection{The moderating effect of organizational justice}

Hierarchical regression analysis is a suitable method for testing moderation effect. According to Table 5, only regression coefficient of interaction term in model 12 is significant, which indicates that organizational justice has a significant adjustment impact on only the relationship between job engagement and CWB; its regression coefficient is -.15 , indicating that organizational justice has a significant negative adjustment impact on only the relationship between job engagement and counterproductive work behavior (CWB). Other adjustment impacts are not significant.

Table 5. The moderating effect of organizational justice

\begin{tabular}{|c|c|c|c|c|c|c|c|c|c|c|c|c|}
\hline & \multicolumn{3}{|c|}{ Job Burnout } & \multicolumn{3}{|c|}{ Task Performance } & \multicolumn{3}{|l|}{ OCB } & \multicolumn{3}{|l|}{ CWB } \\
\hline & Model 1 & Model 2 & 2 Model 3 & 3 Model 4 & 4 Model 5 & 5 Model 6 & 6 Model 7 & 7 Model 8 & 8 Model 9 & $9^{\mathrm{Mo}}$ & $\begin{array}{rr}\text { el } & \text { Model } \\
0 & 11 \\
\end{array}$ & $\begin{array}{rr}\text { Model } \\
1 & 12 \\
\end{array}$ \\
\hline Gender & .01 & .01 & .02 & -.03 & -.04 & -.04 & .02 & .02 & .02 & .04 & .04 & .04 \\
\hline Birth Year & -.10 & -.09 & -.09 & .10 & .09 & .08 & -.01 & -.03 & -.02 & .05 & .07 & .06 \\
\hline Degree & -.08 & -.08 & -.08 & .01 & .00 & .00 & -.02 & -.03 & -.03 & .00 & .00 & .00 \\
\hline Position & .03 & .00 & .00 & .00 & .03 & .03 & .00 & .02 & .02 & .06 & .04 & .05 \\
\hline Working Years & -.09 & -.05 & -.06 & .02 & -.02 & -.03 & -.01 & -.05 & -.03 & -.08 & -.05 & -.08 \\
\hline Enterprise Scale & .08 & .08 & .08 & -.04 & -.05 & -.05 & -.01 & -.02 & -.02 & $.11^{*}$ & $.12^{* *}$ & $.12^{* *}$ \\
\hline Team Size & .01 & .03 & .03 & -.02 & -.02 & -.02 & .01 & .00 & .01 & $-.09^{*}$ & $-.09^{*}$ & $-.09^{*}$ \\
\hline Job Engagement & & $-.27^{* * *}$ & $-.26^{* * *}$ & & $.25^{* * *}$ & $.27^{* * *}$ & & $.30^{* * *}$ & $.29^{* * *}$ & & $-.26^{* * *}$ & $*=-.22^{* * *}$ \\
\hline Organizational Justice & & .08 & .11 & & $.10^{*}$ & .14 & & $.13^{*}$ & .08 & & $-.19^{* * *}$ & $* .08$ \\
\hline Job & & & & & & & & & & & & \\
\hline Engagement $\times$ Organizationa & & & -.04 & & & -.05 & & & .06 & & & $-.15^{* *}$ \\
\hline Justice & & & & & & & & & & & & \\
\hline Adjusted $R^{2}$ & .00 & .10 & .10 & .00 & .04 & .04 & -.01 & .05 & .05 & .01 & .06 & .07 \\
\hline$\Delta R^{2}$ & 0 & .10 & 0 & 0 & .04 & 0 & 0 & .06 & 0 & 0 & .05 & .01 \\
\hline F value & .98 & $7.04^{* * *}$ & * $6.37^{* *}$ & $* .76$ & $3.48^{* * *}$ & * $3.18^{* * *}$ & *08 & $4.13^{* * *}$ & * $\quad 3.80^{* * *}$ & ${ }^{*} 1.80$ & $4.82^{* * *}$ & $5.00^{* * *}$ \\
\hline
\end{tabular}

Note. $p<.05^{*} ; \quad p<.01^{* *} ; \quad p<.001^{* * *}$. 


\subsection{Conclusions of Data Analysis}

In this paper, a total of 7 hypotheses were put forward. After the empirical research, the results are as follows in table 6 .

Table 6. Research hypotheses and conclusions

\begin{tabular}{|c|c|c|}
\hline Hypotheses & Hypothetical Condition & Conclusion \\
\hline Hypothesis 1 & $\begin{array}{l}\text { The job engagement of the employees will increase job performance; that is, job engagement is positively } \\
\text { related to job performance. }\end{array}$ & Supported \\
\hline Hypothesis 1a & $\begin{array}{l}\text { The job engagement of the employees will increase core task performance; that is, job engagement is } \\
\text { positively related to core task performance. }\end{array}$ & Supported \\
\hline Hypothesis $1 \mathrm{~b}$ & $\begin{array}{l}\text { The job engagement of the employees will increase the performance of Organizational Citizenship } \\
\text { Behavior; that is, job engagement is positively related to the performance of Organizational Citizenship } \\
\text { Behavior. }\end{array}$ & Supported \\
\hline Hypothesis 1c & $\begin{array}{l}\text { The job engagement of the employees will decrease counterproductive behavior; that is, job engagement } \\
\text { is negatively related to counterproductive behavior. }\end{array}$ & Supported \\
\hline Hypothesis 2 & $\begin{array}{l}\text { The job engagement of the employees will increase job burnout; that is, job engagement is positivelyly } \\
\text { related to job burnout. }\end{array}$ & $\begin{array}{l}\text { Not } \\
\text { Supported }\end{array}$ \\
\hline Hypothesis 3 & $\begin{array}{l}\text { Organizational Justice plays a negatively moderate role in the relationship between job engagement and } \\
\text { job burnout; that is, the lower the degree of organizational justice, the higher the influential degree of job } \\
\text { engagement on job burnout. }\end{array}$ & $\begin{array}{l}\text { Not } \\
\text { Supported }\end{array}$ \\
\hline Hypothesis 4a & $\begin{array}{l}\text { Organizational justice has a positive moderating effect on the relationship between job engagement and } \\
\text { core task performance. }\end{array}$ & $\begin{array}{l}\text { Not } \\
\text { Supported }\end{array}$ \\
\hline Hypothesis $4 \mathrm{~b}$ & $\begin{array}{l}\text { Organizational justice has a positive moderating effect on the relationship between job engagement and } \\
\text { organizational citizenship behavior. }\end{array}$ & $\begin{array}{l}\text { Not } \\
\text { Supported }\end{array}$ \\
\hline Hypothesis $4 \mathrm{c}$ & $\begin{array}{l}\text { Organizational justice has a negative moderating effect on the relationship between job engagement and } \\
\text { counterproductive work behaviors. }\end{array}$ & Supported \\
\hline
\end{tabular}

\section{Discussion of the Results and Management Implications}

This study suggests that a high degree of job engagement may lead to job burnout, and when employees invest too much energy in their work, they may lead to job burnout. However, from the perspective of empirical analysis, job engagement negatively affects job burnout, that is, the more job engagement is, the less job burnout is. Maslach, Schaufeli, and Leiter (2001) argued that the job burnout and job engagement was an opposite concept, job engagement is individual employee will fully devote themself into their work role, focus and show their performance physiologically, cognitively and emotionally (Kahn, 1990). And then exhibit commitment, satisfaction and love for their job (Dyne \& Vandewalle, 2000), therefore when the staff were actively engaged in the work, this may not result in job burnout.

Job engagement positively affects task performance and organizational citizenship behavior, and job engagement negatively affects the counterproductive work behaviors. This shows that managers need to actively mobilize the enthusiasm and initiative of the staff, and induce them to engage in work positively and whole-heartedly, so that it can increase the task performance and reduce the counterproductive work behaviors.

Organizational justice has a significant negative moderating effect on job engagement and counterproductive work behavior. Counterproductive work behavior refers to employee behaviors which will cause harm to the organization and its members (Dalal, 2005). The employee behaviors causing damage to the organization and its member have a negative effect on the organization and members of the organization, and these counterproductive work behaviors not only has the permeability, may also cause great harm to the organization and employees, thus derived a lot of unnecessary costs.

In the study of management, some scholars took a further discussion on the formation of counterproductive work behavior from the point of view of organizational justice, employee justice perception. The empirical study found that employees will use negative emotion to response the unfair treatment, such as: angry, criminal organization, hatred of supervisor or discipline, and revenge language and behavior (Skarlicki \& Folger, 1997). 
When individuals feel that the organization is not fair to their own, individual psychological unbalance will lead to a range of responsive behaviors, and thus have a negative impact on organizational energy. These behaviors include: theft, vandalism, sabotage, reduction of citizenship behavior, retreat, and unwilling to cooperate with the policy (unwilling to change) (Greenberg, 1990). Therefore, organizational justice may negatively interfere with the impact of employee's job engagement on counterproductive work behavior.

In the management level, the organization is particularly important to create a fair environment as well as a fair attitude. It is suggested that the manager can make explicit statement through the open system and relevant regulations, and the meeting will be held at different hierarchical representation to reduce the organizational justice. The senior supervisor should regularly inspect and listen to the voice of the staff at the grassroots level or reward employees with constructive suggestions, promote fair multiple communication channels.

\section{Research Limitations and Future Research Recommendations}

This study is based on the impact of human and material resources, randomly chose the salesmen of 48 computer sales companies in Nanjing, China. Therefore, the conclusions of this study may be limited to the general rules and application of other industrial management. In addition, a cross-sectional study was conducted in this study, and the inference of causal relationships between variables must be cautious. Finally, all of the questionnaire data collected from the same source, there may have a flaw of the common method bias. Based on this reason, the research suggests that future research can use research methods of longitudinal section, and extend the research objects to other industries, in order to improve the results of reference value. In order to avoid the defects of common method bias, it is suggested that future research should use different sources (such as the measurement of organizational citizenship behavior can be obtained by colleagues), to improve or avoid the defects of common method bias.

\section{References}

Adler, M., \& Rogers. (2006). Job performance deficits due to depression. American Journal of Psychiatry, 163(9), 1569-1576. http://dx.doi.org/10.1176/ajp.2006.163.9.1569

Ambrose, M. L., \& Schminke, M. (2009). The role of overall justice judgments in organizational justice research: a test of mediation. Journal of Applied Psychology, 94(2), 491-500. http://dx.doi.org/10.1037/a0013203

Avey, J. B., Luthans, F., \& Youssef, C. M. (2010). The Additive Value of Positive Psychological Capital in Predicting Work Attitudes and Behaviors. Journal of Management: Official Journal of the Southern Management Association, 36(2), 430-452. http://dx.doi.org/10.1177/0149206308329961

Baumann, N., \& Kuhl, J. (2005). Positive Affect and Flexibility: Overcoming the Precedence of Global over Local Processing of Visual Information. Motivation \& Emotion, 29(2), 123-134. http://dx.doi.org/10.1007/s11031-005-7957-1

Bell, B. S., Wiechmann, D., \& Ryan, A. M. (2006). Consequences of organizational justice expectations in a $\begin{array}{llll}\text { selection system. Journal of Applied Psychology, 91(2), 455-466. } & \text {. }\end{array}$ http://dx.doi.org/10.1037/0021-9010.91.2.455

Bennett, R. J., \& Robinson, S. L. (2000). Development of a measure of workplace deviance. Journal of Applied Psychology, 85(3), 349-360. http://dx.doi.org/10.1037/0021-9010.85.3.349

Biggs, A., Brough, P., \& Barbour, J. P. (2014). Strategic alignment with organizational priorities and work engagement: A multi-wave analysis. Journal of Organizational Behavior, 35(35), 301-317. http://dx.doi.org/10.1002/job.1866

Blickle, G., Wendel, S., \& Ferris, G. R. (2010). Political skill as moderator of personality - Job performance relationships in socioanalytic theory: Test of the getting ahead motive in automobile sales. Journal of Vocational Behavior, 76(2), 326-335. http://dx.doi.org/10.1016/j.jvb.2009.10.005

Brooke, P. P., Russell, D. W., \& Price, J. L. (1988). Discriminant Validation of Measures of Job Satisfaction, Job Involvement, and Organizational Commitment. Journal of Applied Psychology, 73(2), 139-145. http://dx.doi.org/10.1037/0021-9010.73.2.139

Brown, S. P., \& Leigh, T. W. (1996). A new look at psychological climate and its relationship to job involvement, effort, and performance. Journal of Applied Psychology, 81(4), 358-368. http://dx.doi.org/10.1037/0021-9010.81.4.358

Christen, M., Iyer, G., \& Soberman, D. (2013). Job Satisfaction, Job Performance, and Effort: A Reexamination Using Agency Theory. Journal of Marketing, 70(1), 137-150. http://dx.doi.org/10.1509/jmkg.2006.70.1.137 
Colquitt, \& Shaw, J. (2005). How Should Organizational Justice Be Measured? Handbook of Organizational Justice, 34(6), 113-152.

Custers, R., \& Aarts, H. (2005). Positive affect as implicit motivator: on the nonconscious operation of behavioral goals. Journal of Personality \& Social Psychology, 89(2), 129-142. http://dx.doi.org/10.1037/0022-3514.89.2.129

Diefendorff, J. M., Brown, D. J., Kamin, A. M., \& Lord, R. G. (2002). Examining the roles of job involvement and work centrality in predicting organizational citizenship behaviors and job performance. Journal of Organizational Behavior, 23(1), 93-108. http://dx.doi.org/10.1002/job.123

Dyne, \& Vandewalle. (2000). Collectivism, propensity to trust and self-esteem as predictors of organizational citizenship in a non-work setting. Journal of Organizational Behavior, 21(1), 3-23.

Greenberg, J. (2004). Managing workplace stress by promoting organizational justice. Organizational Dynamics, 33(4), 352-365.

Greenberg, J. (2010). A Taxonomy of organizational justice theories. Academy of Management Review, 12(1), 9-22. http://dx.doi.org/10.5465/AMR.1987.4306437

Hackman, J. R., \& Lawler, E. E. (1971). Employee reaction to job characteristics. Journal of Applied Psychology, 55(3), 259-286. http://dx.doi.org/10.1037/h0031152

Hakanen, J. J., Perhoniemi, R., \& Toppinen-Tanner, S. (2008). Positive gain spirals at work: From job resources to work engagement, personal initiative and work-unit innovativeness. Journal of Vocational Behavior, 73(1), 78-91. http://dx.doi.org/10.1016/j.jvb.2008.01.003

Hallberg, U. E., \& Schaufeli, W. B. (2006). "Same Same" But Different? Can Work Engagement Be Discriminated from Job Involvement and Organizational Commitment? European Psychologist, 11(2), 119-127.

Heponiemi, T., Manderbacka, K., Vänskä, J., \& Elovainio, M. (2013). Can organizational justice help the retention of general practitioners? Health Policy, 110(1), 22-28. http://dx.doi.org/10.1016/j.healthpol.2013.02.001

Hoffman, B. J., Blair, C. A., Meriac, J. P., \& Woehr, D. J. (2007). Expanding the criterion domain? A quantitative review of the OCB literature. Journal of Applied Psychology, 92(2), 555-566. http://dx.doi.org/10.1037/0021-9010.92.2.555

Lee, K., \& Allen, N. J. (2002). Organizational citizenship behavior and workplace deviance: the role of affect $\begin{array}{lllll}\text { and } & \text { cognitions. Journal of Applied Pychology, }\end{array}$ http://dx.doi.org/10.1037/0021-9010.87.1.131

Maslach, C., \& Jackson, S. E. (1981). The measurement of experienced burnout. Journal of Organizational Behavior, 2(2), 99-113. http://dx.doi.org/10.1002/job.4030020205

Maslach, Schaufeli, \& Leiter. (2001). Job Burnout. Annual Review of Psychology, 52(1), 397-422. http://dx.doi.org/10.1146/annurev.psych.52.1.397

Ng, T. W., \& Feldman, D. C. (2008). The Relationship of Age to Ten Dimensions of Job Performance. Journal of Applied Psychology, 93(2), 392-423. http://dx.doi.org/10.1037/0021-9010.93.2.392

Niehoff, B. P., \& Moorman, R. H. (1993). Justice as a mediator of the relationship between methods of monitoring and organizational citizenship behavior. Academy of Management Journal, 36(3), 527-556.

Orpen, C. (1997). The effects of formal mentoring on employee work motivation, organizational commitment and job performance. Learning Organization, 4(2), 53-60. http://dx.doi.org/10.1108/09696479710160906

Penney, L. M., \& Spector, P. E. (2005). Job stress, incivility, and counterproductive work behavior (CWB): the moderating role of negative affectivity. Journal of Organizational Behavior, 26(26), 777-796. http://dx.doi.org/10.1002/job.336

Rotundo, M., \& Sackett, P. R. (2002). The relative importance of task, citizenship, and counterproductive performance to global ratings of job performance: a policy-capturing approach. Journal of Applied Psychology, 87(1), 66-80. http://dx.doi.org/10.1037/0021-9010.87.1.66

Rupp, D. E., Ganapathi, J., Aguilera, R. V., \& Williams, C. A. (2006). Employee reactions to corporate social responsibility: an organizational justice framework. Journal of Organizational Behavior, 27(4), 537-543. http://dx.doi.org/10.1002/job.380 
Saks, A. M. (2006). Antecedents and consequences of employee engagement. Journal of Managerial Psychology, 21(7), 600-619. http://dx.doi.org/10.1108/02683940610690169

Schaufeli, \& Bakker. (2004). Job demands, job resources, and their relationship with burnout and engagement: a multi-sample study. Journal of Organizational Behavior, 25(3), 293-315. http://dx.doi.org/10.1002/job.248

Schaufeli, W. B., \& Van Dierendonck, D. (1993). The construct validity of two burnout measures. Journal of Organizational Behavior, 14(7), 631-647.

Schaufeli, W. B., Bakker, A. B., \& Rhenen, W. V. (2009). How changes in job demands and resources predict burnout, work engagement, and sickness absenteeism. Journal of Organizational Behavior, 30(7), 893-917. http://dx.doi.org/10.1002/job.595

Schaufeli, W. B., Salanova, M., González-Romá, V., \& Bakker, A. B. (2002). The Measurement of Engagement and Burnout: A Two Sample Confirmatory Factor Analytic Approach. Journal of Happiness Studies, 3(1), 71-92.

Scott, K. D., \& Mcclellan, E. L. (1990). Gender Differences in Absenteeism. Public Personnel Management, 19(2), 229-253. http://dx.doi.org/10.1177/009102609001900210

Smith, C. A., Organ, D. W., \& Near, J. P. (1983). Organizational Citizenship Behavior: Its Nature and Antecedents. Journal of Applied Psychology, 68(4), 653-663. http://dx.doi.org/10.1037/0021-9010.68.4.653

Sonnentag, S. (2003). Recovery, work engagement, and proactive behavior: A new look at the interface between nonwork and work. Journal of Applied Psychology, 88(3), 518-528. http://dx.doi.org/10.1037/0021-9010.88.3.518

Tsui, A. S., Pearce, J. L., Porter, L. W., \& Tripoli, A. M. (1997). Alternative approaches to the employee-organization relationship: Does investment in employees pay off? Academy of Management Journal, 40(5), 1089-1121.

Warr, P., \& Inceoglu, I. (2012). Job engagement, job satisfaction, and contrasting associations with person-job fit. Journal of Occupational Health Psychology, 17(2), 129-138. http://dx.doi.org/10.1037/a0026859

Wong, P. A. (2000). Professional accountants' work value, organizational commitment and job performance.

Xanthopoulou, D., Bakker, A. B., Demerouti, E., \& Schaufeli, W. B. (2009). Reciprocal relationships between job resources, personal resources, and work engagement. Journal of Vocational Behavior, 74(3), 235-244. http://dx.doi.org/10.1016/j.jvb.2008.11.003

\section{Copyrights}

Copyright for this article is retained by the author(s), with first publication rights granted to the journal.

This is an open-access article distributed under the terms and conditions of the Creative Commons Attribution license (http://creativecommons.org/licenses/by/4.0/). 